\title{
UPAŃSTWOWIENIE SALEZJAŃSKIEGO DOMU DZIECKA W JACIĄŻKU (1951) W POSTPAMIĘCI
}

\author{
The Nationalization of the Salesian Orphanage in Jaciążek (1951) \\ in Postmemory
}

S u $\mathrm{m} m$ a r $\mathrm{y}$ : The article reconstructs and interprets the events that led up to the nationalization of the Salesian orphanage in Jaciążek in 1951. In the study I use the concept of postmemory and the method of qualitative analysis of cultural texts in which the witnesses of the event - the Salesians and their pupils - expressed their traumatic experiences. In spite of differences between the two groups, the main cause of trauma for both was the pseudo-educational activities of the promoters of socialist ideology. In conclusion, I suggest that we recognize socialist pedagogy as a separate instantiation of pseudo-education.

Keyword s: postmemory, demoralisation, socialism, pseudo-education, Catholic education

\section{Wprowadzenie}

Wkrótce po ustaniu działań wojennych w 1945 roku katolickie zakony żeńskie i męskie, stowarzyszenia społeczne i kurie diecezjalne przystąpiły do reaktywowania swojej działalności szkolnej i wychowawczej. Za niedługo jednak ich zapał został stłumiony. „Nowa władza” kamuflowała swoje skrajnie antyreligijne nastawienie tylko na początku. Po umocnieniu się przystąpiła do otwartej walki z Kościołem katolickim i programowej akcji likwidowania prowadzonych przez niego lub w powiązaniu z nim instytucji edukacyjnych. Nieliczne katolickie szkoły i placówki

${ }^{1}$ Ks. dr hab. Dariusz Stępkowski, prof. UKSW - pracownik Wydziału Nauk Pedagogicznych w Uniwersytecie Kardynała Stefana Wyszyńskiego w Warszawie. Adres do korespondencji: ul. Wójcickiego 1/3, 01-938 Warszawa; e-mail: d.stepkowski@uksw.edu.pl. 
opiekuńczo-wychowawcze, którym udało się przetrwać okres stalinizmu w Polsce (1948-1956), zostały ponownie przetrzebione po odwilży październikowej 1956 roku. Władze komunistyczne zostawiły ich jeszcze tylko parę, żeby móc wykazać przed światową opinią publiczną, że w Polskiej Rzeczypospolitej Ludowej (PRL) panuje pełna demokracja i nie prześladuje się Kościoła katolickiego².

Szkoły i placówki opiekuńczo-wychowawcze reaktywowane przez Towarzystwo Salezjańskie (salezjanów) ${ }^{3}$ doświadczyły tego samego losu co przytłaczająca większość instytucji katolickich. W dotychczasowych badaniach rozpatrywano programową akcję likwidowania „zakładów salezjańskich”4 $\mathrm{z}$ reguły od strony instytucjonalnej i faktograficznej ${ }^{5}$. Znacznie mniej miejsca i uwagi poświęcono w nich osobistym przeżyciom uczestników tamtych wydarzen - zarówno salezjanów, jak i ich wychowanków. Wyjątkowo wyraźnie słabość nastawienia obiektywistycznego uzmysławia książka ks. Bronisława Kanta ${ }^{6}$ poświęcona kasacie salezjańskiego domu dziecka w Jaciążku ${ }^{7}$. Mimo że swoim zakresem obejmuje ona całość dziejów salezjanów w tej małej miejscowości na Kurpiowszczyźnie, centralne miejsce zajęły w niej reminiscencje przeżyć autora $\mathrm{z}$ wydarzeń związanych $\mathrm{z}$ upaństwowieniem tamtejszego domu dziecka, który w latach 1945-1951 prowadzili salezjanie.

Poniższy artykuł odbiega od klasycznych opracowań historyczno-pedagogicznych, w których na pierwszy plan wysuwają się kryteria naukowości, takie jak wierność faktom i bezstronność narracji. Perspektywę poznawczą skrótowo definiuje wprowadzony przez Marianne Hirsch i Leo Spitzera termin „postpamięć” (ang. postmemory) ${ }^{8}$. W ich wspólnej publikacji konotuje on wiedzę na temat Holocaustu tworzoną przez osoby, które nie przeżywały bezpośrednio nazistowskiego koszmaru, jednak zrekonstruowały go na podstawie zachowanych wytworów kultury i empatii, czyniąc niejako swoim własnym doświadczeniem. Terminu „postpamięć” używa się obecnie nie tylko do

${ }^{2} \mathrm{~W}$ sprawie zwalczania religii jako przedmiotu szkolnego i katolickich instytucji edukacyjnych w dwu pierwszych dziesięcioleciach PRL zob. Elwira J. Kryńska, Stanisław W. Mauersberg, Indoktrynacja młodzieży szkolnej w Polsce w latach 1945-1956 (Białystok: TransHumana, 2003), 12-52; Sabina Bober, Walka o dusze dzieci i młodzieży w pierwszym dwudziestoleciu Polski Ludowej (Lublin: Wydawnictwo KUL 2011), 293-358.

${ }^{3}$ Jan Pietrzykowski, Waldemar Żurek, Zenon Klawikowski, „Salezjanie”, w: Encyklopedia katolicka, red. Edward Gigilewicz et al., t. 17 (Lublin: Katolicki Uniwersytet Lubelski Jana Pawła II - Towarzystwo Naukowe Katolickiego Uniwersytetu Lubelskiego Jana Pawła II, 2012), 920-926.

${ }^{4}$ Tradycyjne określenie ośrodka szkolno-wychowawczego prowadzonego przez salezjanów.

${ }^{5}$ Waldemar Żurek, Salezjańskie szkolnictwo ponadpodstawowe w Polsce 1900-1963. Rozwój i organizacja (Lublin: Wydawnictwo KUL, 1996), 371-424; Jarosław Wąsowicz, „Likwidacja salezjańskich zakładów wychowawczych". Biuletyn IPN 4 (2007): 49-56; Jan Niewęgłowski, Wychowawczo-społeczna działalność salezjanów w Polsce w latach 1898-1989 (Warszawa: Towarzystwo Naukowe Franciszka Salezego 2011), 509-607.

${ }^{6}$ Ks. Bronisław Kant - ur. 25 II 1930 roku w Glodeni (Rumunia), zm. 11 V 2016 roku w Warszawie. Wstąpił do Zgromadzenia Salezjańskiego w 1947 roku, po odbyciu rocznego przygotowania (nowicjatu) w Czerwińsku nad Wisłą. Święcenia kapłańskie przyjął w Płocku 15 VI 1957 roku. Autor kilkudziesięciu publikacji o charakterze pastoralnym (duszpasterskim), hagiograficznym, historycznym i pamiętnikarskim.

${ }^{7}$ Bronisław Kant, Jaciążek, czyli jak Polska Ludowa demoralizowała młodzież (Warszawa: Parafia Rzymskokatolicka Najświętszego Serca Jezusowego, 2014).

${ }^{8}$ Marianne Hirsch, Leo Spitzer, Ghosts of Home. The Afterlife of Czernowitz in Jewish Memory (Berkeley - Los Angeles - London: University of California Press, 2010), 9. 
„spóźnionej pamięci” drugiego i następnych pokoleń ofiar Holocaustu, lecz również do oznaczenia narracji rekonstrukcyjnych na temat traumatycznych doświadczeń innych narodów, grup społecznych, a nawet pojedynczych osób. W prezentowanym tekście służy on do wyrażenia takiego sposobu obchodzenia się z przeszłością, w którym na pierwszy plan wysuwają się osobiste doznania i emocje salezjanów i ich wychowanków - uczestników nacechowanych dramatyzmem wydarzeń z 1951 roku. Autor tekstu dąży do głębszego zrozumienia tego, co się wówczas dokonało w Jaciążku. Żeby takie zrozumienie osiągnąć, nie wystarcza tylko odtworzyć przebieg zdarzeń i opisać uczestniczące w nich osoby. Z perspektywy postpamięci o wiele ważniejszy jest wysiłek polegający na wniknięciu w „nastrój” czy „klimat” pozostawionych śladów pamięciowych i wytworzenie na ich podstawie więzi rozumienia empatycznego. Taki wysiłek zostanie podjęty przez autora niniejszego opracowania, który jest salezjaninem. Mimo że wydarzenia z salezjańskiego domu dziecka w Jaciążku z 1951 roku nie mają żadnego związku z Holocaustem ani nie da się porównać traumy doświadczonej przez ofiary jednego i drugiego zdarzenia historycznego, zasadne wydaje się wykorzystanie koncepcji postpamięci, która umożliwia przezwyciężenie przerwy spowodowanej mniej lub bardziej zawinioną niepamięcią.

Tok rozważań podzielono na trzy części. W pierwszej zostaną zarysowane dzieje obecności salezjanów w Jaciążku, ze szczególnym uwzględnieniem wydarzeń, które doprowadziły do upaństwowienia w 1951 roku prowadzonego przez nich domu dziecka. Druga część zawiera charakterystykę wytworów kultury wytwarzanych jako materiał wspomnieniowy do postpamięciowej rekonstrukcji traumy wywołanej likwidacją placówki opiekuńczo-wychowawczej - zarówno po stronie salezjanów, jak i ich wychowanków. Narrację powstałą na podstawie analizy tych wytworów zaprezentowano w części trzeciej. Na zakończenie autor zreasumował badanie i sformułował postulat uznania zjawiska demoralizacji nie za skutek programowej indoktrynacji ideologicznej prowadzonej w czasach PRL wśród dzieci i młodzieży, lecz za osobny fenomen pedagogiczny mający charakter pseudowychowania.

\section{Wybrane fakty historyczne}

Jaciążek to niewielka miejscowość położona około 90 kilometrów na północny-wschód od Warszawy, w powiecie makowskim. Pierwsza salezjańska placówka szkolno-wychowawcza powstała tutaj z inicjatywy Stanisława Domaradzkiego (1863-1942) i jego małżonki Zofii (1869-1940), którzy w 1928 roku przekazali Towarzystwu Salezjańskiemu cały swój majątek jako darowiznę z przeznaczeniem na zaopiekowanie się ubogą młodzieżą. Nieco wcześniej, bo w 1925 roku, S. Domaradzki rozpoczął na własną rękę budowę ośrodka szkolno-wychowawczego. Budowę tę dokończyli salezjanie w 1932 roku?

\footnotetext{
9 Kant, Jaciążek, 11-16.
} 
W zakładzie salezjańskim w Jaciążku przyszli rzemieślnicy kształcili się początkowo w czterech specjalnościach: stolarskiej, kołodziejskiej, kowalskiej i ślusarskiej, a po reformie szkolnictwa zawodowego tylko w dwóch: stolarskiej i kołodziejskiej ${ }^{10}$. Jak podaje inny historyk salezjański: „Uczniowie w Jaciążku wyspecjalizowali się w produkcji bryczek konnych, tzw. wolantów"11.

$\mathrm{Z}$ powodu sporego oddalenia od większych miejscowości i związanych z tym trudności komunikacyjnych brakowało w Jaciążku kandydatów na rzemieślników. Z tego powodu w roku szkolnym 1933/1934 zdecydowano się na otwarcie czteroklasowego Małego Seminarium Duchownego dla spóźnionych powołań, tzw. Synów Maryi. W pierwszym roku naukę w Małym Seminarium rozpoczęło 38 uczniów. W kolejnych latach ich liczba wzrastała, osiągając w ostatnim roku szkolnym przed II wojną światową $193^{12}$. Co do liczby uczących się zawodów rzemieślniczych, brakuje dokładnych danych. Przypuszcza się, że wahała się ona w różnych latach między 30 a $80^{13}$.

We wrześniu 1939 roku zakład salezjański zajęli Niemcy, przekształcając go w ośrodek szkoleniowy Hitlerjugend. W 1945 roku uciekając przed zbliżającą się Armią Sowiecką, opróżnili go z mebli i zdewastowali ${ }^{14}$. Jak pisze ks. B. Kant, „już w kwietniu 1945 roku [salezjanie] otworzyli gimnazjum dla aspirantów [tj. dla uczniów niższego seminarium - dop. D.S.], którzy mieli uzupełnić studia gimnazjalne i uzyskać maturę przed wstąpieniem do Zgromadzenia [Salezjańskiego]”15.

Jak doszło do powstania w Jaciążku domu dziecka, opisuje następująco naoczny świadek tamtych lat, ks. B. Kant: „Na początku września [1945 roku - dop. D.S.] przyjechali z Warszawy naczelnik i inspektorka Opieki Społecznej, by nakłonić Salezjanów do otwarcia sierocińca, choćby tylko dla 50 sierot. Obiecywano, że [...] dostarczą koksu i ropy do motoru. (Motor był źródłem światła elektrycznego wieczorami)"16. Przyjęcie sierot wymagało jednak przygotowania, choćby prowizorycznego, pomieszczeń pozbawionych jakichkolwiek mebli. Ksiądz B. Kant opisuje przyjazd pierwszych wychowanków, cytując kronikę zakładu salezjańskiego: „18 października - [...] Około południa i po południu przyjechała pierwsza grupa dzieci z okolicznych gmin. Było ich trzydzieścioro kilkoro. Dziś też pierwszy raz było czynne centralne ogrzewanie. Dzieci są przeważnie z bunkrów. Budzą wielkie współczucie"17.

W następnym roku szkolnym, tj. 1946/1947, w salezjańskim domu dziecka przebywało już 240 chłopców i około 100 dziewcząt. Tymi ostatnimi zajmowały się siostry salezjanki. Sierociniec dziewczęcy działał niecały rok. Wiosną 1947 roku

10 Jan Pietrzykowski, „Formy działalności salezjanów w Jaciążku 1928-2003. Zarys”. Seminare. Poszukiwania naukowe 21 (2005): 49.

11 Niewęgłowski, Wychowawczo-społeczna, 309.

12 Tamże, 310.

13 Pietrzykowski, „Formy”, 49.

14 Tamże, 53-54.

15 Kant, Jaciążek, 31.

16 Tamże, 32.

17 Tamże, 34. 
siostry salezjanki przeniosły swoje wychowanki do innych placówek. Na ich miejsce przyjęto następną grupę chłopców ${ }^{18}$.

Na początku roku szkolnego 1947/1948 liczba wychowanków w domu dziecka osiągnęła niebotyczne $365^{19}$. Przekraczało to znacznie możliwości lokalowe i aprowizacyjne placówki. Ksiądz B. Kant wspomina: „Byliśmy właścicielami olbrzymiego majątku, a nie mieliśmy mleka” ${ }^{20}$. Wynikało to stąd, że już w 1946 roku grunty należące do salezjanów zostały upaństwowione ${ }^{21}$. Produkty konieczne do wyżywienia wychowanków i kadry wychowawczej pochodziły przeważnie od zagranicznych organizacji pomocowych, takich jak Duński Czerwony Krzyż czy United Nations Relief and Rehabilitation Administration (UNRRA; Administracja Narodów Zjednoczonych do spraw Pomocy i Odbudowy), gdyż organy i instytucje państwowe nie wywiązywały się z wcześniejszych deklaracji wspierania działalności domu dziecka. Co gorsza, zajęły się wcielaniem w życie dyrektyw ofensywy ideologicznej, nowej polityki kulturalnej i społecznej, którą zainicjował Komitet Centralny Polskiej Partii Robotniczej w celu przyśpieszenia procesu sowietyzacji Polski ${ }^{22}$.

Przed rozpoczęciem roku szkolnego 1948/1949 państwowe organy nadzoru przeprowadziły w salezjańskim domu dziecka w Jaciążku roszadę. „Dotychczasowi wychowankowie zostali przewiezieni do państwowych ośrodków wychowawczych. $\mathrm{Na}$ ich miejsce zostali przysłani chłopcy z marginesu społecznego"23. Bezpośredni uczestnik tamtych wydarzeń, ks. B. Kant, wspomina:

Obecni wychowankowie przysłani przez kuratorium to przeważnie chłopcy, którzy przeszli przez kilka zakładów wychowawczych i poprawczych, z którymi wychowawcy nie mogli sobie poradzić. Na przykład przysłano nam na resocjalizację dwóch wychowanków po lat 17 , aby pobyli tu do pełnoletności. Nazywali się Sieczka i Piętka. Jeden dotychczas pracował w milicji [podkr. D.S.] i postrzelił czy zastrzelił człowieka, a drugi służył w straży pożarnej [podkr. D.S.] i podpalał domy, by później być pierwszym przy gaszeniu. Ci wnosili wiele bałaganu do zakładu i jak najgorzej wpływali na dotychczasowych wychowanków ${ }^{24}$.

Celem tych działań nie była wcale troska o dobro nieletnich przestępców, lecz zakłócenie relacji pedagogicznych i wywołanie w domu dziecka skandalu, co dostarczyłoby organom nadzoru pretekstu do upaństwowienia domu dziecka. Od

18 Niewęgłowski, Wychowawczo-społeczna, 581.

19 Kant, Jaciążek, 49.

20 Tamże, 41.

21 Posiadłość przekazana salezjanom przez Stanisława i Zofię Domaradzkich obejmowała 343-hektarowe gospodarstwo, w tym 182 ha ziemi ornej, 37 ha łąk i pastwisk, 88 ha lasów liściastych i iglastych, 14 ha stawów rybnych i 6 ha ogrodów. Pietrzykowski, „Formy”, 48.

${ }_{22}$ Kryńska, Mauersberg, Indoktrynacja, 64-67; Teresa Hejnicka-Bezwińska, Zarys historii wychowania (1944-1989) (oświata i pedagogika pomiędzy dwoma kryzysami) (Kielce: Wydawnictwo Pedagogiczne ZNP, 1996), 55-91.

${ }_{23}$ Niewęgłowski, Wychowawczo-społeczna, 582.

${ }^{24}$ Kant, Jaciążek, 49. 
listopada 1950 roku działania prowokatorskie nasiliły się jeszcze bardziej. Tak opisuje je ks. B. Kant:

[Ostatecznie] władza [posłużyła się] dziewczyną, lat około 18-20, aktywistką partyjną. Została ona zatrudniona w szkole podstawowej w Jaciążku jako opiekunka harcerstwa i Związku Młodzieży Polskiej (ZMP) Nazywała się Maria Majkowska, a potocznie Maryśka, gdyż była z chłopcami na »ty«. Czasami chłopcy nazywali ją »pieszczotliwie« Rozwalochą ${ }^{25}$.

Choć prowokatorce nie udało się wywołać skandalu w domu dziecka, to jednak jej wysiłki przyniosły przewidywane owoce. Postępowanie wychowanków względem salezjanów (wychowawców) stawało się z dnia na dzień coraz gorsze, aż w końcu przekroczyło wszelkie dopuszczalne normy. „Do porządku dziennego należało rzucanie kamieniami w okna, kopanie w drzwi pokoi oraz obrzucanie wyzwiskami wychowawców. Następnie wychowankowie agresję swoją okazywali w niszczeniu. Spalili wszystkie książki i zeszyty, rozbijali talerze i kubki w stołówce oraz demolowali sypialnie i wyposażenie studiów ${ }^{26}{ }^{27}$. Te i inne jeszcze oznaki zdemoralizowania zmusiły dyrektora do przekazania salezjańskiego domu dziecka władzom państwowym, co dokonało się w dniu 13 kwietnia 1951 roku $^{28}$.

Kasacja salezjańskiego domu dziecka w Jaciążku została przeanalizowana od strony instytucjonalnej i faktograficznej w kilku opracowaniach historycznych ${ }^{29}$. Ich autorzy wykorzystali przede wszystkim materiały archiwalne i epistolarne, takie jak: statuty, zarządzenia, pisma, kroniki, korespondencję prywatną i urzędową itp. W mniejszym stopniu powołują się na materiały narracyjne, takie jak pamiętniki, wspomnienia, relacje ustne i pisemne. Tymczasem $\mathrm{z}$ perspektywy celu przyświecającego temu badaniu zawarty w tego typu materiałach autobiograficznych punkt widzenia i ocena wydarzeń wydają się szczególnie interesujące i warte wydobycia na światło dzienne. Umożliwiają bowiem odtworzenie osobistych przeżyć uczestników zdarzeń historycznych i empatyczne wczucie się w ich doświadczenia.

\section{Co przechowało się dla postpamięci?}

Rekonstrukcja postpamięciowa wymaga sięgnięcia po wytwory kultury, w których uczestnicy wydarzeń wyeksplikowali swoje przeżycia i traumę nimi spowodowaną. Do subiektywno-empatycznego odtworzenia wydarzeń z 1951 roku zostaną wykorzystane następujące wytwory: (1) przywoływana już wielokrotnie książka

25 Tamże, 78.

26 Studium - w zakładzie salezjańskim pomieszczenie przeznaczone do nauki.

27 Niewęgłowski, Wychowawczo-społeczna, 583.

${ }_{28}$ Kant, Jaciążek, 82; Niewęgłowski, Wychowawczo-społeczna, 583; Pietrzykowski, „Formy”, 57.

29 Żurek, Salezjańskie, 384; Niewęgłowski, Wychowawczo-społeczna, 581-583; Pietrzykowski, „Formy”, $56-58$. 
ks. B. Kanta ${ }^{30}$, (2) zapiski zatytułowane Sodoma i Gomora autorstwa nieznanego salezjanina, który podpisał się pseudonimem „Jim Jonet”, i (3) powieść Remigiusza Napiórkowskiego, byłego wychowanka salezjańskiego domu dziecka w Jaciążku³1.

Odnośnie do książki ks. B. Kanta należy wyjaśnić, że napisał ją ponad sześćdziesiąt lat po wydarzeniach, których był bezpośrednim uczestnikiem. Nie oparł się jednak wyłącznie na swojej pamięci, lecz wykorzystał materiały dokumentalne pochodzące z archiwum parafialnego w Jaciążku i Archiwum Salezjańskiego Inspektorii Warszawskiej (ASIW) w Warszawie. Z ich pomocą prowadzi w swojej książce narrację, którą uzupełnia reminiscencjami przeżyć i osobistymi refleksjami na temat trzech lat spędzonych w domu dziecka w Jaciążku jako asystent ${ }^{32}$. Były to lata szkolne: 1945/1946, 1947/1948 i 1950/1951. Jak te lata i pozostawiony przez nie w pamięci ślad były ważne dla ks. B. Kanta, może świadczyć fakt, że ich rekonstrukcje zajmują w książce więcej niż połowę stron ${ }^{33}$. Znacznie bardziej emocjonalnym dowodem tego jest pozostawiony przez autora opis jego reakcji po przeczytaniu zapisek nieznanego salezjanina, Jima Joneta. Ksiądz B. Kant zanotował: „Wczytując się w tekst, przeżywałem na nowo wszystkie te wydarzenia, przez co spędziłem kilka nocy bezsennych, a w inne noce przeżywałem we śnie istny koszmar, gdy mi się śniły te wydarzenia" ${ }^{34}$. Zanim skupimy uwagę na traumie spowodowanej kasatą salezjańskiego domu dziecka w Jaciążku, trzeba wyjaśnić, dlaczego ks. B. Kant spisał swoje przeżycia dopiero po sześciu dziesięcioleciach.

We wprowadzeniu do omawianej książki ks. B. Kant wyjaśnia, że przedstawia w niej po raz trzeci swoje doświadczenia z pobytu w Jaciążku. Pierwszy raz opisał je "jako świadectwo tamtych czasów" 35 na polecenie przełożonego zakonnego, ks. Stanisława Rokity (1900-1984), wkrótce po zlikwidowaniu domu dziecka i po powrocie na studia filozoficzno-teologiczne do Wyższego Seminarium Duchownego Towarzystwa Salezjańskiego w Krakowie. Oczywiście wersja ta była znacznie bogatsza w szczegóły niż obecna. Autor wspomina: „Spełniłem to polecenie, spisałem jak można najdokładniej, przepisałem na maszynie, introligator oprawił i powstała tak książeczka formatu A5 o objętości około 90 stron" ${ }^{36}$. Materiał został zdeponowany w archiwum, skąd zniknął w bliżej nieznanym czasie i okolicznościach. Gdy po kilku latach zauważono to zniknięcie, na polecenie tego samego przełożonego zakonnego autor złożył ponownie relację pisemną, „ale już krócej i bez nazwisk, bo wiele rzeczy z pamięci uciekło" ${ }^{37}$. Dziwnym trafem również druga wersja opuściła półki

${ }^{30}$ Kant, Jaciążek.

${ }^{31}$ Remigiusz Napiórkowski, Nie będzie płakania (Warszawa: Państwowe Wydawnictwo „Iskry”, 1964).

${ }^{32}$ Asystent - salezjanin odbywający praktykę pastoralno-pedagogiczną w trakcie studiów filozoficzno-teologicznych.

${ }^{33}$ Kant, Jaciążek, 7-9, 31-100, 117-119, 135-141.

34 Tamże, 93.

${ }_{35}$ Tamże, 8.

36 Tamże.

37 Tamże. 
archiwum. Ksiądz B. Kant zauważa: „Ktoś musiał dobrze penetrować dokumenty $\mathrm{w}$ inspektoracie poza władzami inspektorii" ${ }^{38}$.

Zapiski Jima Joneta posłużyły jako drugi wytwór kultury do rekonstrukcji postpamięciowej, którą zawiera następna część niniejszego artykułu. Natrafił na nie przypadkowo ks. B. Kant w ASIW w Warszawie, przygotowując swoją książkę. O zapiskach tych nie wspominano do tej pory w opracowaniach historyków salezjańskich.

Według relacji ks. B. Kanta rękopis składał się z kilkunastu stron. W jego książce cytat $\mathrm{z}$ rękopisu znajduje się na stronach 82-93 (być może to całość). Po nim autor umieścił od siebie cztery uwagi i sprostowania ${ }^{39}$. Niestety manuskrypt nie powrócił do archiwum i publikacja w książce ks. B. Kanta jest jedynym śladem, który po nim się zachował.

Z analizy ks. B. Kanta wynika, że Jim Jonet musiał być bezpośrednim świadkiem wydarzeń z 1951 roku w Jaciążku i opisywał je na bieżąco ${ }^{40}$. Tego, kim był tajemniczy Jim Jonet, nie da się zdaniem ks. B. Kanta ustalić, gdyż w ostatnim roku funkcjonowania salezjańskiego domu dziecka w Jaciążku pracowało w nim 14 salezjanów ${ }^{41}$. Ukrycie się pod pseudonimem ks. B. Kant tłumaczy tym, że autor najwidoczniej „obawiał się konsekwencji, gdyby to opracowanie dostało się w ręce ubeków”"

Trzecim wytworem kultury, który umożliwił skonstruowanie postpamięciowego obrazu wydarzeń z salezjańskiego domu dziecka w Jaciążku w 1951 roku, jest powieść R. Napiórkowskiego pt. Nie będzie płakania. Na obwolucie tej publikacji autor napisał o sobie: „W 1947 roku, po śmierci ojca, matka umieściła mnie w zakładzie księży salezjanów, w Jaciążku. Przebywałem tam kilka lat ${ }^{43}$. Były to w moim życiu dziwne lata i właśnie na motywach przeżyć $z$ tego okresu oparta jest moja powieść". Co do związku powieści z przeżyciami z Jaciążka R. Napiórkowski wyjaśnia w tym samym miejscu:

Nie jest to jednak powieść autobiograficzna. Mam wrażenie, że powieści autobiograficzne pisze się mając lat 70, wtedy, gdy powiedziało się już wszystko o cudzych światach i można spokojnie wrócić do świata swojego. Natomiast pisarz dwudziestokilkuletni, sięgając do motywów autobiograficznych, powinien chyba czynić to tylko dla własnej satysfakcji stworzenia w powieści takiego życia, jakie by chciał przeżyć jeszcze raz, gdyby mógł być po raz drugi chłopcem. Zdaje mi się, że miarą prawdy w takiej literaturze powinien być tylko autentyzm tamtych przerażeń i jakaś szczerość pisarska.

\footnotetext{
38 Tamże, 9.

39 Tamże, 93.

40 Tamże, 79.

41 Pełna lista personelu salezjańskiego znajduje się w omawianej książce na s. 73.

42 Tamże, 9.
}

${ }^{43}$ Na zamieszczonej przez ks. B. Kanta alfabetycznej liście 114 wychowanków, którzy przebywali w salezjańskim domu dziecka w Jaciążku w roku szkolnym 1950/1951, R. Napiórkowski znajduje się na miejscu 73 (Kant, Jaciążek, 75). Był on wówczas uczniem najstarszej klasy - siódmej. Klasa ta była najliczniejsza i najbardziej zaangażowana w działania skierowane przeciw salezjanom. 
Wygłoszone przez R. Napiórkowskiego literackie credo zawiera sprzeczność. $\mathrm{Z}$ jednej strony bowiem autor wzbrania się przed traktowaniem przedłożonego przez niego utworu jako autobiografii, $\mathrm{z}$ drugiej zaś informuje, że dał w nim wyraz „tamtym przerażeniom”, czyli traumie, której doświadczył w salezjańskim domu dziecka w Jaciążku. Odrzucając z góry wierność faktom i kierując się jedynie wolnością literacką, obiecuje zachować „autentyzm” i „jakąś szczerość pisarską”. Nie ulega wątpliwości, że R. Napiórkowskiemu chodzi o autentyzm i szczerość wobec siebie samego. Jeżeli tak, to jego utwór znakomicie nadaje się do niniejszego badania i to wcale nie dlatego, że zawiera zgodną z rzeczywistością relację z wydarzeń, do jakich doszło w Jaciążku w 1951 roku, lecz dlatego, że odzwierciedla subiektywne przeżycia autora jako ich uczestnika.

Bliższych wyjaśnień odnośnie do perspektywy przyjętej przez R. Napiórkowskiego w powieści dostarcza następny akapit tekstu na obwolucie (to jedyne miejsce, gdzie mowa jest o faktach historycznych). Autor pisze w nim:

Przybywając do zakładu księży salezjanów, miałem nieco więcej niż dziesięć lat ${ }^{44}$, ale byłem już człowiekiem na swój sposób dojrzałym. Zetknąłem się tam z ludźmi dorosłymi, dorosłością tego samego rodzaju co moja, kilkunastolatków, którzy widzieli tyle co ludzie kilkudziesięcioletni, takich, którzy nie pamiętali, kto ich urodził, albo takich, którzy nie znali swoich imion i nazwisk... To pokolenie ma obecnie tyle lat co ja i wydaje mi się, że nie można nic prawdziwego powiedzieć dziś o filozofii i psychice mojego pokolenia bez sumiennego przestudiowania chłopięctwa tego pokolenia ${ }^{45}$.

W powyższym cytacie R. Napiórkowski prezentuje swoje pokolenie jako zupełnie inne od dotychczasowych. O odmienności „jego" pokolenia mają przekonywać trzy właściwości, które autor sygnalizuje w tym miejscu, a w całej pełni rozwija na kartach swojej powieści. Właściwości te czynią pokolenie R. Napiórkowskiego do tego stopnia unikatowym, że nie da się go zrozumieć „bez sumiennego przestudiowania chłopięctwa tego pokolenia”. Owe właściwości zostały już wyeksplikowane w przytoczonym powyżej fragmencie, ale warto je powtórzyć. Są to: po pierwsze, przedwczesna dojrzałość, która R. Napiórkowskiemu jako czternastoletniemu chłopcu pozwoliła w 1950 roku uważać się za dorosłego; po drugie, nad wiek poważne doświadczenia, które $\mathrm{z}$ reguły są udziałem osób kilkudziesięcioletnich, i po trzecie, egotyczna indywidualność, która broni przystępu do siebie, zasłaniając się niepowtarzalnym losem.

Z pedagogicznego punktu widzenia zastanawiają nie tylko wymienione pokoleniowe właściwości rówieśników R. Napiórkowskiego, lecz również ich proweniencja. Wbrew spontanicznie narzucającemu się skojarzeniu autor źródłem swojej traumy nie czyni przeżyć wojennych, lecz pobyt w salezjańskim domu dziecka w Jaciążku.

${ }^{44}$ Remigiusz Napiórkowski urodził się 5.12.1936 roku (https://pl.wikipedia.org/wiki/ Remigiusz_Napi\%C3\%B3rkowski).

${ }_{45}$ Napiorkowski, Nie będzie. 
Najwidoczniej czas ten zapisał się w jego pamięci jako bardziej traumatyczny niż niedawno zakończona wojna.

R. Napiórkowski deklaruje, że po latach wrócił do swoich przeżyć z zamiarem „stworzenia w powieści takiego życia, jakie by chciał przeżyć jeszcze raz, gdyby mógł być po raz drugi chłopcem". Gdyby to wyznanie odczytywać przez pryzmat psychoanalizy, natychmiast nasuwa się wyparcie, jeden $z$ freudowskich mechanizmów obronnych. Podmiot wypycha do nieświadomości zagrażające mu z jakiegoś powodu myśli, wspomnienia i uczucia, żeby tylko odzyskać wewnętrzny spokój (sumienia?). Rekonstrukcja postpamięciowa nie ma jednak na celu wyjaśnienia tego zastanawiającego motywu powstania książki R. Napiórkowskiego. Jego wcześniejszy manifest pokoleniowy posłuży w następnej części do zrozumienia sensu wydarzeń, które dokonały się w Jaciążku w roku szkolnym 1950/1951. Wyraźnie widać, że wycisnęły one niezatarty i traumatyczny ślad w pamięci obu stron - salezjanów i ich wychowanków.

\section{Rekonstrukcja postpamięciowa}

Celem rekonstrukcji postpamięciowej nie jest odtworzenie przeszłych wydarzeń zgodnie z porządkiem chronologicznym, w którym się dokonywały. Zainteresowanie badacza skupia się na subiektywnych przeżyciach uczestników wydarzeń i traumie, która pozostawiła ślad w wytworzonych przez nich tworach kultury.

Przegląd zachowanych dla postpamięci materiałów potwierdził, że wydarzenia z roku szkolnego 1950/1951 zapisały się zarówno w pamięci salezjanów, jak i ich wychowanków jako traumatyczne. Na przebieg tych wydarzeń miały z pewnością wpływ wspomnienia wojenne. Ta uwaga dotyczy w równym stopniu salezjanów, jak i ich wychowanków, przy czym ci pierwsi, ze względu chociażby na swój wiek, byli lepiej przygotowani do poradzenia sobie z bolesną przeszłością. Czy i w jakim stopniu salezjanie byli $\mathrm{w}$ stanie pomóc swoim podopiecznym $\mathrm{w}$ uporaniu się $\mathrm{z}$ traumą wojenną, wykracza poza zakres niniejszego opracowania ${ }^{46}$.

Porównując jednak przeżycia ze wspomnianego powyżej roku szkolnego i ich odczytanie przez obie strony, bez większego wysiłku da się zaobserwować odmienność. Tej uwagi nie należy mylnie odnosić do warstwy faktograficznej. Dla R. Napiórkowskiego jest ona bez większego znaczenia, w przeciwieństwie do ks. B. Kanta, który ustosunkowuje się „do pewnych nieścisłości” ${ }^{77}$ zawartych w powieści tego pierwszego. Odtwarzając z pamięci fakty, osoby i zdarzenia,

${ }^{46}$ Zgodnie ze współczesnym stanem wiedzy zjawisko, o którym mowa, zalicza się do Zespołu stresu pourazowego (ang. Post-Traumatic Stress Disorder - PTSD). Kategorię tę stosuje się w psychologii do opisania zaburzeń będących reakcją na skrajnie stresujące wydarzenie, które przekracza zdolności danej osoby do radzenia sobie i adaptacji. Nie jest możliwie określenie, czy i ilu wychowanków cierpiało na PTSD, niemniej jednak należy przypuszczać, że znaczna część.

${ }^{47}$ Kant, Jaciążek, 135. 
salezjanin koryguje nieprawdziwe informacje podane przez R. Napiórkowskiego. Przykładowo, w scenie finałowej jego powieści dwóch wychowanków: autor, który nadaje sobie imię i nazwisko Maciej Krajski, i fikcyjny lider wszystkich wychowanków o przydomku „Rudy”, w proteście przeciwko salezjanom postanawiają wywołać rewolucję. W tym celu wspinają się po drabinie na dzwonnicę kościoła, zamykają za sobą skrzypiące drzwi i ogłaszają głodówkę ${ }^{48}$. Do tego biją w dzwon, żeby cała okolica wiedziała o ich proteście ${ }^{49}$. Ksiądz B. Kant wyjaśnia, że: „Nigdy nie było żadnego wejścia na wieżę na dole. Wejście było [...] ze strychu. Dlatego ani drzwi nie mogły skrzypieć, bo ich nie było, ani drabina, bo też jej nie było"50. A odnośnie do dzwonu ten sam salezjanin pisze: „Cały dowcip polega na tym, że na wieży nigdy nie było dzwonu. Był tylko zbiornik na wodę, gdyż wieża służyła jako wieża ciśnień" ${ }^{\prime \prime}$.

Z punktu widzenia R. Napiórkowskiego uwagi ks. B. Kanta muszą wydawać się zupełnie nieistotne. Nie to bowiem było intencją powieści napisanej przez byłego wychowanka salezjańskiego. Zapewne ks. B. Kant uświadamiał sobie również daremność swoich korekt, gdyż rozpoczął je znamiennym zdaniem: „Zresztą cała treść [powieści R. Napiórkowskiego - dop. D.S.] jest jedną wielką fikcją literacką "52. Paradoksalnie jednak właśnie w powieści tej jako odrealnionej wizji utrwaliły się przeżycia wielu wychowanków salezjańskiego domu dziecka w Jaciążku, których socjalistyczni pseudowychowawcy ${ }^{53}$ i ich mocodawcy wyzwolili spod wpływu wychowania katolickiego i poprowadzili drogą ku pełnej wolności. Żeby uniknąć nieporozumień, trzeba dopowiedzieć, że R. Napiórkowski w swojej powieści jednoznacznie pozytywnie ocenia to wyzwolenie i umożliwienie mu i innym wychowankom stania się człowiekiem dorosłym.

Do tego, żeby zrekonstruować proces socjalistycznej emancypacji dzieci i młodzieży z salezjańskiego domu dziecka w Jaciążku, powieść R. Napiórkowskiego nie nadaje się z dwu omówionych już powodów. Po pierwsze, dlatego, że autor z góry zastrzegł, że nie jest to autobiografia, a jedynie literacka parafraza. Po drugie zaś, dlatego że została napisana z perspektywy bezkrytycznej afirmacji pseudowychowawczych metod działania indoktrynacji socjalistycznej. Pozostają do dyspozycji zapisy i wspomnienia pochodzące od obu salezjanów, dla których fakty nie były obojętne, a wręcz przeciwnie, opisując je, starali się dać wyraz zarówno temu, czego doświadczyli oni sami, jak i temu, z czym musieli się skonfrontować ich wychowankowie. Ci ostatni w większości uważali to za wyzwolenie, ale nie wszyscy i nie do końca.

\footnotetext{
48 Napiórkowski, Nie będzie, 175.

49 Tamże, 176.

50 Kant, Jaciążek, 136.

51 Tamże.

52 Tamże, 135.

53 Terminy „pseudowychowanie”, „pseudowychowawca” i „pseudowychowawczy” są używane w rozumieniu przedstawionym przez Jacka Filka („Fenomenologia wychowania”. W: tegoż, Filozofia jako etyka. Eseje filozoficzno-etyczne (Kraków: Wydawnictwo Znak, 2001), 101-102.
} 
Drobiazgowy opis działań podejmowanych przez pseudowychowawców socjalistycznych w celu zniszczenia integronu edukacyjnego ${ }^{54} \mathrm{w}$ salezjańskim domu dziecka w Jaciążku zawierają pamiętnik Jima Joneta i rekonstrukcja wydarzeń ks. B. Kanta. Dla potrzeb tego opracowania musi wystarczyć ich wypunktowanie i wskazanie na skutki, jakie spowodowały w relacjach pedagogicznych między wychowankami a ich wychowawcami i w interakcjach wychowanków między sobą. W każdym z dwu etapów interwencji pseudowychowawczych skutki te były nieco inne. Cezurę między tymi etapami wyznacza przybycie na początku roku szkolnego 1950/1951 do Szkoły Podstawowej w Jaciążku aktywistki ZMP, o której była mowa już powyżej. Pod jej wpływem interwencje pseudowychowawcze nabrały charakteru nieskrywanej deprawacji dzieci i młodzieży ${ }^{55}$.

Z pierwszego etapu oddziaływań pseudowychowawców socjalistycznych zostały sportretowane we wspomnieniach ks. B. Kanta następujące przejawy amoralnych zachowań wychowanków: (1) wyśmiewanie salezjanów w niecenzuralnych przyśpiewkach na temat księży, (2) akty agresji słownej, zmierzające do sprowokowania salezjanów do użycia przymusu, (3) umyślne niszczenie pomieszczeń i sprzętów, (4) odmowa realizowania programu dnia, (5) szykanowanie współwychowanków okazujących dezaprobatę wobec „walki z salezjanami”, (6) fizyczne przymuszanie niezdecydowanych współwychowanków do przyłączenia się do rebelii, (7) akty agresji fizycznej wobec salezjanów, (8) nękanie dyrektora i w końcu (9) obsceniczne zachowania w obecności salezjanów, którzy jako wychowawcy byli zobowiązani do sprawowania nadzoru pedagogicznego ${ }^{56}$.

Choć mogłoby się wydawać, że działania pseudowychowawców celem zniszczenia relacji pedagogicznych między salezjanami a wychowankami domu dziecka sięgnęły już zenitu, w drugim etapie za sprawą aktywistki ZMP doszło do dalszej eskalacji wpływów demoralizujących. Polegały one na: (1) wykonywaniu czynów lubieżnych w obecności i z wychowankami, (2) namawianiu do przemocy słownej i fizycznej wobec salezjanów, (3) zorganizowaniu grupy („rządu”), której zadaniem było wywołanie buntu, (4) szkalowaniu salezjanów i ich godności osobistej oraz (5) dostarczaniu nieletnim alkoholu i spożywaniu go z nimi ${ }^{57}$.

Zdanie sobie sprawy $z$ deprawacyjnego charakteru wymienionych powyżej działań, które dla przypomnienia, zdaniem R. Napiórkowskiego, uczyniły go wolnym,

${ }^{54}$ Termin ,integron edukacyjny” pochodzi od Romana Schulza. Tym mianem oznacza on dwuczynnikowy układ, który charakteryzuje edusferę. Tworzą go „podmioty edukacyjne kształtujące” i „podmioty edukacyjne kształtowane". Współistnienie i współdziałanie obu tych podmiotów warunkuje proces kształtowania rozwoju ludzkiego i jego skuteczność. Por. Roman Schulz, Edusfera jako holistyczna kategoria pedagogiki ogólnej. Zarys idei (Kraków: Impuls, 2018), 121-127.

${ }_{55}$ O powszechnym zdemoralizowaniu członków i etatowego aktywu ZMP pisze m.in. Marek Wierzbicki, Związek Młodzieży Polskiej i jego członkowie (Warszawa: Wydawnictwo TRIO - Instytut Studiów Politycznych PAN, 2006), 295-344. Odnośnie do roli wyznaczonej ZMP w ofensywie ideologicznej zob. Bober, Walka, 380-389; Kryńska, Mauersberg, Indoktrynacja, 121-146.

${ }^{56}$ Kant, Jaciążek, 79-80.

57 Tamże, 79-80. 
uzmysławia tragizm sytuacji wywołanej z całą premedytacją przez socjalistycznych pseudowychowawców. Naoczny świadek i ofiara wielu z wymienionych powyżej aktów agresji ze strony wychowanków, ks. B. Kant pisze: „Z bólem serca patrzyliśmy na to, jak ci najlepsi coraz bardziej upodabniali się do najgorszych, ale nie mogliśmy w żaden sposób zareagować" ${ }^{58}$. Brak jakichkolwiek możliwości działania wynikał z faktu, że integron edukacyjny został umyślnie zniszczony. Wskutek tego wychowankowie przestali współpracować ze swoimi dotychczasowymi wychowawcami. Ich miejsce zajęli pseudowychowawcy, którzy wkrótce po upaństwowieniu domu dziecka musieli skonstatować, że również oni nie mają żadnej kontroli nad moralnie zepsutymi dziećmi i młodzieżą w domu dziecka w Jaciążku. W związku z tym, jak podaje ks. B. Kant, jeszcze przed rozpoczęciem wakacji najstarsi „zostali zakwalifikowani do szkół górniczych, [...] w rzeczywistości była to praca w kopalni”59.

Kierownictwo [państwowego] domu dziecka zdawało sobie sprawę, że dopóki chociaż jeden z tych, którzy „pomagali” partii upaństwowić zakład salezjański, pozostanie na miejscu, wszyscy nowo przyjęci od nich się zarażą. Nie było innego sposobu na zatamowanie moralnej dżumy, jak tylko wywieźć wszystkich z Jaciążka i porozmieszczać po innych domach dziecka, możliwie pojedynczo lub w bardzo małych grupach ${ }^{60}$.

W ten sposób zawieszono na kilka lat działalność domu dziecka w Jaciążku.

Powyższa rekonstrukcja postpamięciowa byłaby niepełna bez wyjaśnienia, skąd pochodzą rozbieżności między salezjanami a ówczesnym ich wychowankiem, R. Napiórkowskim w postrzeganiu i ocenianiu wydarzeń z 1951 roku. Choć obie sprawy ogląd i ocena - są ściśle ze sobą powiązane, to tutaj zostaną rozważone osobno.

Dysproporcja w oglądzie wynika $\mathrm{z}$ różnicy miejsc zajmowanych $\mathrm{w}$ integronie edukacyjnym. Mówiąc językiem R. Schulza, salezjanie byli tymi, którzy kształtują, a R. Napiórkowski należał do tych, którzy byli kształtowani. Dopóki mamy do czynienia z relacją pedagogiczną, niemożliwe jest zniwelowanie tej różnicy ani odwrócenie ról. Inne zadania mają do spełnienia wychowawcy i inną w związku z tym ponoszą odpowiedzialność niż ci, którzy zostali powierzeni ich pieczy jako wychowankowie. Oczywiście, skuteczność oddziaływań wychowawczych zależy od obu stron, mówiąc inaczej: bez gotowości do współdziałania niemożliwe jest ani bycie wychowywanym, ani wychowywanie innych.

W powyższym świetle pseudowychowawcze oddziaływania zwolenników ideologii socjalistycznej nie tylko zakłóciły współdziałanie wychowanków z salezjanami i vice versa, lecz całkowicie je zniszczyły. Jak należy nazwać to, co się wówczas dokonało?

Dla salezjanów była to jednoznacznie demoralizacja. Z powieści R. Napiórkowskiego wynika, że wyzwolenie (emancypacja). Żeby dobrze zrozumieć charakter

\footnotetext{
58 Tamże, 79.

59 Tamże, 95.

60 Tamże.
} 
tego wyzwolenia, warto przypomnieć atrybuty wyróżniające „dziecięctwo”, którego doświadczyło jego pokolenie: przedwczesna dojrzałość, nad wiek poważne doświadczenia i egotyczna indywidualność. Czy nie są to symptomy deprawacji?

Powyższe potwierdza tytuł nadany swoim zapiskom przez Jima Joneta: Sodoma i Gomora. Podobnie uważa ks. B. Kant, który początkowo chciał nadać swojej książce krótki tytuł Jaciążek ${ }^{61}$. Najwidoczniej praca pamięci i przepracowywanie wydarzeń z przeszłości skłoniły go do zmiany tego zamiaru.

Przez indoktrynację i manipulację ${ }^{62}$ udało się socjalistycznym pseudowychowawcom rozbić integron edukacyjny i zepchnąć salezjanów na pozycję bez możliwości przeciwdziałania ich demoralizującym poczynaniom. Salezjanie przeżywali wydarzenia, w których uczestniczyli, jako ból nie tylko dlatego, że spotykały ich ze strony wychowanków czyny uwłaczające ich osobistej godności, lecz również dlatego, że nie byli w stanie zapobiec największej tragedii - deprawacji swoich wychowanków. Bez cienia wątpliwości za to deprawowanie odpowiadają socjalistyczni pseudowychowawcy, ale jego ofiarą padli wychowankowie salezjanów. Retrospektywnie ks. B. Kant pisze na ten temat: „Sądzę [...], że to zło, jakie w ich duszach zasiała partia w większości wypadków nie tylko zakiełkowało, ale całkowicie nimi zawładnęło"63. Paradoksalnie powieść R. Napiórkowskiego potwierdza to pesymistyczne przekonanie. Zanim zostanie to wykazane, trzeba prześledzić jeszcze jeden wątek zawarty w książce ks. B. Kanta.

W posłowiu do swojej książki o Jaciążku ks. B. Kant przedrukował opis „spotkania z wrakiem"64. Po raz pierwszy opis ten zamieścił jako rozdział w małej broszurze zatytułowanej Zanim będzie za późno ${ }^{65}$. Owym „wrakiem” był napotkany przypadkowo w 1965 roku były wychowanek z salezjańskiego domu dziecka w Jaciążku - Janek. To on sam wyraził się, że stał się „,wrakiem, człowiekiem niepotrzebnym nikomu”66. Ze smutkiem wyznał swojemu dawnemu wychowawcy, że: „Kiedyś, gdy ksiądz miał z nami lekcje religii, gdy nam mówił, jak trzeba żyć, myślałem sobie, jaki ksiądz jest naiwny. A dziś widzę, że to ja właśnie byłem naiwny" ${ }^{67}$. Powodem tej negatywnej samooceny są nakreślone pobieżnie dalsze losy Janka po upaństwowieniu domu dziecka w Jaciążku:

Uwierzyliśmy w to, co nam partia wmawiała. A więc wolność, koledzy, papierosy, wódeczka. Wmawiałem sobie, że przecież w każdej chwili mogę przestać. Potem kradzieże, by było za co pić

61 Tamże, 7.

62 Wojciech Chudy, Społeczeństwo zakłamane. Esej o społeczeństwie i kłamstwie - 1 (Warszawa: Oficyna Naukowa, 2007); tenże, Kłamstwo jako metoda. Esej o społeczeństwie i kłamstwie - 2 (Warszawa: Oficyna Naukowa 2007).

${ }^{63}$ Kant, Jaciążek, 74.

64 Tamże, 140-141.

65 Bronisław Kant, Zanim będzie za późno (Warszawa: Wydawnictwo Salezjańskie, 1991), 3-5.

66 Kant, Jaciążek, 141.

67 Tamże. 
i bawić się, wreszcie napady na ludzi i więzienie, z którego wyszedłem przed tygodniem i chyba znowu tam wrócę, albo się powieszę"68.

Ks. B. Kant przywołuje z pamięci, że:

Był on wtedy w klasie szóstej. Dobrze się zapowiadał. Często bywał dyżurnym. Lubił porządek. Miał wpływ na kolegów i posłuch. Był przywódcą grupy. Miał także duże zdolności. Marzył o karierze wojskowej w lotnictwie ${ }^{69}$.

Warto na powyższy przykład spojrzeć przez pryzmat charakterystyki pokolenia, którą przedstawił R. Napiórkowski. W połowie lat 60. XX wieku autor powieści Nie będzie płakania i opisany przez ks. B. Kanta Janek byli w podobnym wieku, ale ich oceny zdarzeń z 1951 roku wypadały skrajnie przeciwstawnie. Będąc w jaciążkowskim domu dziecka, Janek uważał za nieżyciowego i naiwnego swojego ówczesnego wychowawcę, który z perspektywy religijnej zachęcał wychowanków do przestrzegania zasad moralnych. Pod wpływem późniejszych doświadczeń Janek przyznał, że tamta ocena była mylna i że popełnił w życiu wiele błędów, które sprowadziły go na przestępczą drogę. Winą za to nie obarczał jednak innych, lecz siebie samego i swoje niewłaściwe wybory moralne. Ze słów Janka skierowanych do ks. B. Kanta jasno wynika, że ma on świadomość sprawstwa i poczucie odpowiedzialności za swoją aktualną sytuację. W niczym nie zmienia to jednak tragizmu jego losów.

R. Napiórkowski jako młody i dobrze zapowiadający się eseista i powieściopisarz zaświadcza swoim utworem o pozytywnym postrzeganiu pseudowychowawczych zabiegów socjalistycznych demoralizatorów i dogłębnej wdzięczności im za wyzwolenie (emancypację) spod wpływu wychowania katolickiego, to jednak przez to właśnie przejawia się jeszcze jeden skutek rewolucji kulturowej, do której beneficjentów zalicza siebie samego - cynizm. Zdaniem Leopolda Tyrmanda w czasach stalinowskich pokoleniu młodych Polaków zaszczepiono hipokryzję i obłudę, za sprawą których udawali wiernych wyznawców systemu, drwiąc sobie równocześnie $z$ zasad moralnych czy religijnych ${ }^{70}$. Ten intelektualny i moralny relatywizm należy uznać za równorzędny, jeżeli nie groźniejszy, skutek prowadzonej w tamtych czasach programowo deprawacji młodego pokolenia niż wejście w konflikt z prawem.

\section{Zakończenie}

Dzięki postpamięciowej rekonstrukcji kasaty salezjańskiego domu dziecka w Jaciążku w 1951 roku zostały ukazane traumatyczne doświadczenia zarówno salezjanów, jak i ich wychowanków. Badanie wykazało, że głównym źródłem traumy były pseudowychowawcze działania krzewicieli „moralności socjalistycznej”. Walcząc

\footnotetext{
${ }^{68}$ Tamże.

69 Tamże, 140.

${ }^{70}$ Leopold Tyrmand, Cywilizacja komunizmu (Kraków: Wydawnictwo MG, 2016).
} 
z wrogiem ideologicznym, jakim był dla nich Kościół katolicki, przez deprawację, czyli sprowadzanie na złą drogę osób niedojrzałych i bezbronnych wobec oddziaływań manipulacyjnych, skierowali oni wychowanków przeciwko swoim wychowawcom. Chociaż salezjański dom dziecka w Jaciążku został upaństwowiony, prawdziwą i najwyższą cenę za to zapłacili wychowankowie. W przezwyciężeniu traumy spowodowanej przeżyciami wojennymi starali się im pomóc salezjanie-wychowawcy środkami wychowania religijnego. $\mathrm{W}$ trudnym okresie powojennym byli oni jednak zajęci przede wszystkim organizowaniem aprowizacji i podstawowej edukacji dla swoich podopiecznych. Natomiast w państwowej placówce edukacyjnej, jaką była Szkoła Podstawowa w Jaciążku, wychowankowie zostali poddani celowemu znieprawianiu, które w znacznej części skutecznie pozbyło ich hamulców moralnych i zachęciło do postępowania amoralnego. To skłania do zrewidowania spojrzenia na prowadzoną programowo w czasach PRL wśród dzieci i młodzieży demoralizację.

Jak do tej pory brakuje analiz dotyczących zachowań i postaw wywołanych przez pedagogię socjalistyczną. Najczęstszym przedmiotem zainteresowania badaczy są działania indoktrynacyjne, które obejmowały szkołę i środowisko pozaszkolne. Na podstawie przedstawionego materiału i jego interpretacji nasuwa się refleksja, że rysem charakterystycznym wychowania socjalistycznego była nie tylko indoktrynacja, lecz również demoralizacja. Tę ostatnią należy traktować nie jako skutek wszczepiania dzieciom i młodzieży ideologii socjalizmu, lecz jako odrębną konkretyzację pseudowychowania, na równi z wychowaniem nieadekwatnym, fikcyjnym i wyobcowanym, o których pisał swego czasu Jacek Filek ${ }^{71}$. Paradoksalnie we współczesnej leksykografii pedagogicznej termin „demoralizacja” jest w ogóle nieobecny ${ }^{72}$ lub tylko skrótowo ${ }^{73}$. Równie rzadko lub wcale nie mówi się o demoralizacji i (pseudo)wychowaniu demoralizującym w pedagogice resocjalizacyjnej ${ }^{74}$.

Patrząc na przeżycia salezjanów i ich wychowanków z domu dziecka w Jaciążku wywołane wydarzeniami z roku szkolnego 1950/1951, nieodparcie nasuwa się refleksja, że socjalistyczni pseudowychowawcy celowo użyli wobec dzieci i młodzieży oddziaływań deprawacyjnych jako narzędzia do osiągnięcia swoich celów ideologicznych. W tych okolicznościach trzy filary wychowania salezjańskiego - rozum,

71 Filek, „Fenomenologia”, 102-117.

72 Wincenty Okoń, Nowy słownik pedagogiczny (Warszawa: Wydawnictwo Akademickie „Żak”, 2007).

${ }^{73}$ Małgorzata Kupisiewicz, Słownik pedagogiki specjalnej (Warszawa: Akademia Pedagogiki Specjalnej im. M. Grzegorzewskiej - WN PWN, 2013), 67.

${ }^{74}$ Bruno Hołyst, Wiktymologia (Warszawa: Wydawnictwo Prawnicze LexisNexis, 2006); Anetta Jaworska, Leksykon resocjalizacji (Kraków: Impuls, 2012); Mariusz Sztuka, „Współczesność resocjalizacyjna: zdemoralizowana czy zadiaforyzowania?". W: Demoralizacja, resocjalizacja i readaptacja. Aktualne problemy, wyzwania i możliwości, red. Małgorzata H. Kowalczyk, Michał Szykut (Toruń: Wydawnictwo Edukacyjne „Akapit”, 2016), 17-29. 
miłość wychowawcza i religia ${ }^{75}$ - okazały się zbyt mało skuteczne, żeby zachować spoistość integronu edukacyjnego, a w dalszej kolejności ustrzec wychowanków przed demoralizacją.

Salezjanie wychowawcy, którzy pracowali w domu dziecka w Jaciążku, zwłaszcza w ostatnich, jakże trudnych i bolesnych latach jego funkcjonowania, zdali celująco egzamin z myślenia pedagogicznego. Pomimo upokorzeń, szykan i prześladowań, których doświadczyli ze strony swoich wychowanków, nie sprzeniewierzyli się etosowi pedagoga i moralności katolickiej. Zasługę przypisywali jednak nie sobie, lecz Bożej Opatrzności. Aż trzy razy w swojej książce ks. B. Kant wyznaje, że tylko „dzięki nadzwyczajnej opiece Bożej"76 udało im się przetrwać najgorsze chwile i udaremnić realizację głównego celu pseudoemancypatorów, jakim było zdyskredytowanie w oczach opinii publicznej salezjanów jako reprezentantów wychowania katolickiego.

Stres z c z e n i e: W artykule przedstawiono rekonstrukcję i interpretację wydarzeń, które doprowadziły do upaństwowienia salezjańskiego domu dziecka w Jaciążku w 1951 roku. W badaniu posłużono się koncepcją postpamięci i metodą jakościowej analizy wytworów kultury, w których uczestnicy wydarzeń - salezjanie i ich wychowankowie - wyrazili swoje traumatyczne doznania. Mimo różnic głównym powodem traumy dla obu uczestniczących w nich stron były pseudowychowawcze działania krzewicieli ideologii socjalistycznej. W konkluzji autor postuluje uznanie pedagogii socjalistycznej za odrębną formę (konkretyzację) pseudowychowania.

Słow a kluczowe: postpamięć, demoralizacja, socjalizm, pseudowychowanie, wychowanie katolickie

\section{Bibliografia}

Bober, Sabina. Walka o dusze dzieci i młodzieży w pierwszym dwudziestoleciu Polski Ludowej. Lublin: Wydawnictwo KUL, 2011.

Chudy, Wojciech. Kłamstwo jako metoda. Esej o społeczeństwie i kłamstwie - 2. Warszawa: Oficyna Naukowa, 2007.

Chudy, Wojciech. Społeczeństwo zakłamane. Esej o społeczeństwie i kłamstwie - 1. Warszawa: Oficyna Naukowa, 2007.

Filek, Jacek. „Fenomenologia wychowania”. W: tegoż, Filozofia jako etyka. Eseje filozoficzno-etyczne, 82-117. Kraków: Wydawnictwo Znak, 2001.

Hejnicka-Bezwińska, Teresa. Zarys historii wychowania (1944-1989) (oświata i pedagogika pomiędzy dwoma kryzysami). Kielce: Wydawnictwo Pedagogiczne ZNP, 1996.

Hirsch, Marianne, Spitzer, Leo. Ghosts of Home. The Afterlife of Czernowitz in Jewish Memory. Berkeley - Los Angeles - London: University of California Press, 2010.

Hołyst, Bruno. Wiktymologia. Warszawa: Wydawnictwo Prawnicze LexisNexis, 2006.

${ }^{75}$ Zob. Kazimierz Misiaszek, „Pedagogia salezjanów [Towarzystwa św. Franciszka Salezego]”. W: Pedagogie katolickich zgromadzeń zakonnych. Historia i wspótczesność, t. 1, red. Janina Kostkiewicz (Kraków: Impuls, 2012), 229-269.

${ }^{76}$ Kant, Jaciążek, 8, 82, 93. 
Jaworska, Anetta. Leksykon resocjalizacji. Kraków: Impuls, 2012.

Kant, Bronisław. Jaciążek, czyli jak Polska Ludowa demoralizowała młodzież. Warszawa: Parafia Rzymskokatolicka Najświętszego Serca Jezusowego, 2014.

Kant, Bronisław. Zanim będzie za późno. Warszawa: Wydawnictwo Salezjańskie, 1991.

Kryńska, Elwira J., Mauersberg, Stanisław W. Indoktrynacja młodzieży szkolnej w Polsce w latach 1945-1956. Białystok: TransHumana, 2003.

Kupisiewicz, Małgorzata. Słownik pedagogiki specjalnej. Warszawa: Akademia Pedagogiki Specjalnej im. M. Grzegorzewskiej - WN PWN, 2013.

Misiaszek, Kazimierz. „Pedagogia salezjanów [Towarzystwa św. Franciszka Salezego]”. W: Pedagogie katolickich zgromadzeń zakonnych. Historia i współczesność, t. 1, red. Janina Kostkiewicz, 229-269. Kraków: Impuls, 2012.

Napiórkowski, Remigiusz. Nie będzie płakania. Warszawa: Państwowe Wydawnictwo „Iskry”, 1964.

Niewęgłowski, Jan. Wychowawczo-społeczna działalność salezjanów w Polsce w latach 1898-1989. Warszawa: Towarzystwo Naukowe Franciszka Salezego, 2011.

Okoń, Wincenty. Nowy słownik pedagogiczny. Warszawa: Wydawnictwo Akademickie „Żak”, 2007.

Pietrzykowski, Jan. „Formy działalności salezjanów w Jaciążku 1928-2003: zarys”. Seminare. Poszukiwania Naukowe 21 (2005): 47-60.

Pietrzykowski, Jan, Waldemar Żurek, Zenon Klawikowski. „Salezjanie”. W: Encyklopedia katolicka, red. Edward Gigilewicz et al., t. 17, 920-926. Lublin: Katolicki Uniwersytet Lubelski Jana Pawła II - Towarzystwo Naukowe Katolickiego Uniwersytetu Lubelskiego Jana Pawła II, 2012.

Schulz, Roman. Edusfera jako holistyczna kategoria pedagogiki ogólnej. Zarys idei. Kraków: Impuls, 2018.

Sztuka, Mariusz. „Współczesność resocjalizacyjna: zdemoralizowana czy zadiaforyzowania?”. W: Demoralizacja, resocjalizacja i readaptacja. Aktualne problemy, wyzwania i możliwości, red. Małgorzata H. Kowalczyk, Michał Szykut, 17-29. Toruń: Wydawnictwo Edukacyjne „Akapit”, 2016.

Tyrmand, Leopold. Cywilizacja komunizmu. Kraków: Wydawnictwo MG, 2016.

Wąsowicz, Jarosław. „Likwidacja salezjańskich zakładów wychowawczych”. Biuletyn IPN 4 (2007): 49-56. Wierzbicki, Marek. Związek Młodzieży Polskiej i jego członkowie. Warszawa: Wydawnictwo TRIO Instytut Studiów Politycznych PAN, 2006.

Żurek, Waldemar. Salezjańskie szkolnictwo ponadpodstawowe w Polsce 1900-1963. Rozwój i organizacja. Lublin: Wydawnictwo KUL, 1996. 